\title{
PENINGKATAN SIKAP PERCAYA DIRI MELALUI STRATEGI PEMBELAJARAN ATONG BERBANTU MEDIA POWTOON DI SEKOLAH DASAR
}

\author{
Wening Wulandari ${ }^{1}$, Aji Heru Muslim ${ }^{2}$, Pratik Hari Yuwono ${ }^{3}$ \\ ${ }^{123}$ Program Studi PGSD Universitas Muhammadiyah Purwokerto \\ Email: weningwulandari1106@gmail.com
}

\begin{abstract}
This study aimed to improve the students confidence through ATONG learning strategies with Powtoon-based video as the media. The subjects were the students of class V of Primary School that consisted of 26 students, 13 female and 13 male students. It was a Classroom Action Research that conducted in 2 cycles. Each cycle consisted of one meeting with the allocation time of $6 \times 35$ minutes for each meeting. The procedure of each cycle consisted of planning, acting, observing, and reflecting. The data on the results of self-confidence were obtained by using questionnaires, observations, and documents. In cycle 1, based on the questionnaire, the students self-confidence in the learning process obtained 74.23 with good criteria and based on the observation, the students selfconfidence in the learning process obtained 3.67 with good criteria. In cycle II, based on the questionnaire, it increased to 86 with very criteria, and based on the observation sheet, it increased to 3,992 with good criteria. Therefore, it can be concluded that ATONG learning strategy with the Powtoon-based video as the media is able to improve the students self-confidence in class V of Primary School.
\end{abstract}

Keywords: Confidence, ATONG Learning Strategies, Powtoon

\begin{abstract}
Abstrak. Penelitian ini bertujuan untuk meningkatkan sikap percaya diri siswa menggunakan strategi pembelajaran ATONG dengan bantuan media video berbasis powtoon. Subyek penelitian adalah siswa kelas V Sekolah Dasar dengan jumlah 26 yang terdiri dari 13 perempuan dan 13 laki-laki. Penelitian ini adalah Penelitian Tindakan Kelas dalam 2 siklus. Setiap siklus terdiri dari 1 pertemuan dengan masing-masing pertemuan terdiri dari 6x35 menit. Prosedur pelaksanaan setiap siklus terdiri dari perencanaan, pelaksanaan, tindakan, observasi dan refleksi. Data hasil sikap percaya diri siswa diperoleh dari angket, observasi dan dokumen. Pada siklus 1 hasil angket yang diperoleh siswa dalam proses pembelajaran yaitu 74,23 dengan kriteria baik dan hasil dari lembar observasi sikap percaya diri yang diperoleh siswa dalam proses pembelajaran yaitu 3,67 dengan kriteria baik, pada siklus II mengalami peningkatan menjadi 86 dengan kriteria baik sekali dan hasil dari lembar observasi sikap percaya diri mengalami peningkatan 3,99 dengan kriteria baik. Dengan demikian dapat disimpulkan bahwa strategi pembelajaran ATONG dengan bantuan media video berbasis powtoon dapat meningkatkan sikap percaya diri siswa kelas $\mathrm{V}$ Sekolah Dasar.
\end{abstract}

Kata Kunci: Sikap Percaya Diri, Strategi Pembelajaran ATONG, Powtoon

Wening Wulandari, dkk: Peningkatan Sikap Percaya Diri Melalui Strategi Pembelajaran ATONG Berbantu Media POWTOON Di Sekolah Dasar I 


\section{PENDAHULUAN}

Sekolah dasar merupakan jenjang pendidikan yang paling dasar pada pendidikan formal yang memegang peranan penting bagi perkembangan siswa. Pendidikan pada sekolah dasar harus memberikan bekal yang dapat mengembangkan pengetahuan, keperibadian, maupun keterampilan yang ada dalam diri siswa. Pemerintah Indonesia telah melakukan berbagai upaya untuk meningkatkan kualitas pendidikan yang ada di Indonesia salah satunya dengan penyempurnaan kurikulum.

Kurikulum 2013 yang merupakan kurikulum baru yang digunakan saat ini tidak hanya menekankan kepada penguasaan kompetensi siswa, melainkan juga pembentukan karakter siswa. Sasaran penerapan kurikulum 2013 adalah untuk mewujudkan kompetensi sikap, pengetahuan dan ketrampilan siswa sebagai peserta didik. Ketiga kompetensi dasar tersebut diharapkan dapat membangun kesiapan generasi muda dalam menghadapi Masyarakat Ekonomi ASEAN (MEA). Yusnimar (2016: 95) MEA adalah sebuah integrasi ekonomi ASEAN dalam menghadapi perdagangan bebas antar negara-negara ASEAN. Kedatangan MEA nanti akan menjadikan satu negara akan mudah menjual barang dan jasa ke negara lain diseluruh Asia Tenggara, sehingga akan terjadi persaingan kompetensi yang semakin ketat. Barang siapa mampu bersaing akan diberdayakan, dan barang siapa tidak mampu bersaing akan tersingkirkan. Oleh karena itu MEA dapat menjadi ancaman bagi yang tidak memiliki kompetensi dan dapat menguntungkan bagi yang memiliki kompetensi. Untuk mendukung terciptanya generasi muda yang berkompetensi dan mampu memberikan gagasan, memiliki sikap berani, tekun, semangat kerja keras dan gairah untuk berkarya di era global maka kompetensi yang dikembangkan di dalam kurikulum, khusunya kompetensi sikap siswa dalam mendukung kegiatan proses pembelajaran adalah kepercayaan diri siswa.

Membangun kepercayaan diri siswa bertujuan agar siswa memiliki keberanian dalam mengekspresikan ide, pemikiran, serta gagasan secara abstrak maupun mewujudnyatakan dalam ranah konkret yang selanjutnya dapat membantu berkembangnya prestasi belajar siswa. Hal ini senada dengan pendapat Suhardita (2011:130) seseorang yakin pada diri sendiri baik itu tingkah laku, emosi, dan kerohanian yang bersumber dari hati nurani untuk mampu melakukan segala sesuatu sesuai dengan kemampuannya untuk memenuhi kebutuhan hidup agar lebih bermakna, seseorang merasa dirinya berharga dan mampu menjalani kehidupan, mempertimbangkan berbagi pilihan dan membuat keputusan sendiri. Sikap rasa percaya diri pada siswa hendaknya ada dalam pembelajaran. Siswa harus yakin dengan apa yang menjadi keputusannya maupun segala sesuatu yang dilakukannya dalam pembelajaran. Sikap percaya diri ini menjadi hal yang penting karena dengan percaya diri siswa dapat mengikuti pembelajaran dengan baik dan dapat berperan aktif di dalamnya.

Memiliki sikap percaya diri merupakan hal yang sangat penting untuk menunjang proses pembelajaran. Dengan sikap percaya diri maka siswa akan lebih mudah menemukan kelebihan dan kekurangan demi perbaikan dan 
meningkatkan kualitas dirinya. Siswa yang aktif dan percaya diri pada saat proses pembelajaran di kelas akan lebih mudah menemukan kelebihan dan kekurangan dibandingkan dengan siswa yang pasif dan minder dalam proses pembelajaran. Orang yang percaya diri selalu yakin pada tindakan yang dilakukannya dan bertanggung jawab atas tindakannya. Hal tersebut tentu mempermudah dalam proses belajarnya. Keberhasilan dalam proses belajar maka akan mempengaruhi prestasi belajar siswa.

Kurangnya sikap percaya diri siswa, maka perlu adanya upaya untuk pengembangan rasa percaya diri siswa yaitu dengan unjuk diri menggunakan strategi pembelajaran yang menarik, sehingga anak dapat tertarik dan rasa percaya diri anak meningkat. Salah satu strategi pembelajaran yang menarik digunakan dalam proses pembelajaran adalah dengan menggunakan strategi pembelajaran ATONG. Strategi pembelajaran ATONG merupakan pengembangan dari pendekatan Scientific yang di dalamnya terdapat aktivitas siswa dalam melakukan suatu penemuan. Penemuan tersebut akan dilaksanakan dalam tahap nalar dan gagas yang diharapkan dapat berpikir secara logis berdasarkan informasi-informasi yang diperoleh serta dapat meningkatkan rasa percaya diri siswa ketika menyampaikan informasi yang telah siswa peroleh melalui tahapan-tahapan sebelumnya tentang materi yang sedang dipelajari, selain menggunakan strategi ATONG peneliti juga menggunakan media powtoon sebagai alat untuk membantu guru mempermudah menyampaikan materi pelajaran kepada siswa. Penggunaan media video berbasis powtoon menjadikan tampilan presentasi di depan kelas menjadi lebih menarik. Sehingga siswa antusias dan bergairah dalam mengikuti proses pembelajaran.

Rumusan masalah dalam penelitian ini adalah bagaimana strategi pembelajaran ATONG dengan bantuan media video berbasis powton dapat meningkatkan sikap percaya diri siswa kelas V SD Negeri 1 Karangduren?. Tujuan diadakan penelitian ini untuk mengetahui peningkatan sikap percaya diri melalui strategi pembelajaran ATONG dengan bantuan media video berbasis powton. Manfaat dalam penelitian ini diharapkan dapat menjadi kajian dan bahan pengembangan untuk memantapkan pemahaman teori tentang peningkatan sikap percaya diri dan prestasi belajar melalui strategi pembelajaran ATONG dengan bantuan media video berbaisis powton. Berdasarkan rumusan maslalah di atas, maka diadakan penelitian yang berjudul" "Peningkatan Sikap Percaya Diri Siswa melalui Strategi Pembelajaran ATONG dengan bantuan Media Video Berbasis powtoon Kelas V SD Negeri 1 Karangduren".

\section{METODE}

Penelitian ini akan dilaksanakan di SD N 1 Karangduren semester genap tahun pelajaran 2019/2020 Waktu penelitian akan dilaksanakan pada bulan Januari-Februari 2020. jumlah siswa sebanyak 26 yang terdiri dari 13 siswa perempuan dan 13 siswa laki-laki.

Penelitian ini adalah penelitian tindakan kelas yang dilaksanakan dalam 
dua siklus. Setiap siklus terdiri dari satu pertemuan. Penelitian tindakan kelas merupakan suatu gambaran proses dinamis keempat aspek penelitian ini harus dipahami yaitu perencanaan, tindakan, observasi dan refleksi. Penelitian tindakan kelas ini dilakukan oleh peneliti dengan berkolaborasi bersama Guru kelas VA SD Negeri 1 Karangduren. Subjek dalam penelitian ini adalah siswa kelas V SD Negeri 1 Karangduren Kecamatan Sokaraja Kabupaten Banyumas pada semester II tahun pelajaran 2019/2020.

Penelitian ini menggunakan tiga teknik pengumpulan data yaitu observasi, angket, dan dokumen. Observasi digunakan untuk mengamati kegiatan siswa dalam proses pembelajaran, faktor yang diamati adalah keaktifan siswa dalam pembelajaran, keaktifan siswa dalam bertanya, keaktifan siswa dalam menanggapi atau menyampaikan pendapatnya dan digunakan untuk mengetahui seberapa besar sikap percaya diri siswa yang ditampilkan saat mengikuti proses pembelajaran. Selain melakukan kegiatan observasi peneliti juga melakukan kegiatan dokumentasi agar peneliti mempunyai alat pencatatan untuk menggambarkan apa yang terjadi dikelas pada waktu pembelajaran dan sebagai pengumpulan data dalam bentuk tulisan yang berupa bukti nyata yang digunakan untuk membantu dalam pembuatan laporan penelitian. Setelah mengetahui hasil dari observasi dan dokumen yang telah dilakukan, peneliti membagikan angket pada setiap akhir siklus untuk melihat peningkatan sikap percaya diri siswa pada setiap siklus. Penelitian ini merupakan Penelitian Tindakan Kelas (PTK) yang mengambil tempat penelitian di sekolah dasar dalam rangka meningkatkan kualitas pembelajaran. Arikunto (2010: 3) mengemukakan bahwa penelitian tindakan kelas merupakan suatu pencermatan terhadap kegiatan belajar berupa sebuah tindakan, yang sengaja dimunculkan dan terjadi dalam sebuah kelas secara bersamaaan. Tindakan tersebut diberikan oleh guru atau dengan arahan dari guru yang dilakukan oleh siswa. Penelitian ini menggunakan prosedur penelitian tindakan kelas direncanakan dua siklus. Apabila belum berhasil akan dilanjutkan siklus berikutnya. Kegiatan setiap siklus terdiri dari: perencanaan (planning), tindakan (acting), observasi (observerving), dan refleksi (reflecting). Adapun prosedut penelitian ditunjukan dengan diagram pada gambar 1 di bawah ini, bentuk desain penelitian tindakan kelas dari Kemmis \& MC Taggart.

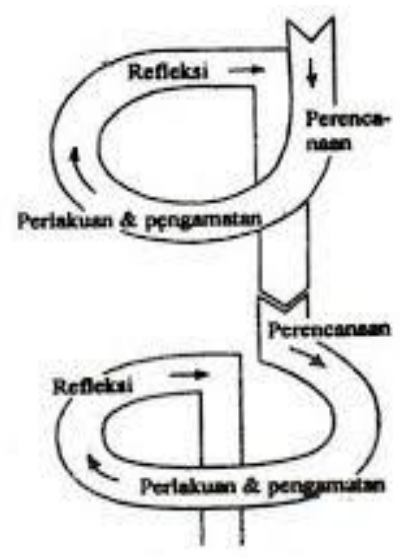

Gambar 1. Alur dalam PTK

\section{HASIL DAN PEMBAHASAN}

Hasil dari pelaksanaan tindakan kelas yang dilaksanakan di kelas $\mathrm{V}$ SD $\mathrm{N}$ Karangduren pada tema 6 panas dan perpindahannya subtema 1 yakni Suhu dan Kalor dan subtema 2 Perpindahan 


\section{Jurnal Riset Pendidikan Dasar (JRPD)}

Kalor di Sekitar kita menggunakan strategi ATONG dengan bantuan media video berbasis powtoon, mendapatkan hasil yaitu peningkatan sikap percaya diri siswa dari siklus I dan siklus II. Meningkatnya sikap percaya diri dapat terlihat dari saat proses pembelajaran yang dibuktikan dengan data lembar angket, lembar observasi dan dokumen. Angket diberikan kepada siswa pada akhir setiap siklus. Angket tersebut berisi 20 pernyataan yang telah disesuaikan dengan indikator percaya diri menurut mulyasa (2014: 146) yaitu pantang menyerah, berani menyatakan pendapat, berani bertanya, mengutamakan usaha sendiri dari pada bantuan, dan berpenampilan tenang. Cara pengisian lembar angket ini siswa hanya memilih jawaban sesuai dengan yang siswa alami atau rasakan selama proses pembelajaran untuk mencapai hasil prestasi yang maksimal. Penilaian angket percaya diri siswa menggunakan skala guttman Proses pengisian angket percaya diri ini menggunakan tanda $(\sqrt{ })$ pada alternatif pilihan jawaban $\mathrm{Y}$ (Ya) T (Tidak).

Hal yang diukur melalui angket berdasarkan indikator antara lain pantang menyerah memiliki 5 deskriptor, berani menyatakan pendapat 5 deskriptor, berani bertanya 3 deskriptor, mengutamakan usaha sendiri memiliki 4 deskriptor, dan berpenampilan tenang memiliki 3 deskriptor. Hasil peningkatan rasa percaya diri siswa dapat dilihat pada tabel 1 sebagai berikut:
Tabel 1 Hasil Peningkatan Angket Sikap Percaya Diri Siswa

\begin{tabular}{cccc}
\hline No & $\begin{array}{c}\text { Pencapain } \\
\text { percaya diri } \\
\text { siswa }\end{array}$ & Siklus I & Siklus II \\
\hline 1 & Rata-Rata & 74,23 & 86 \\
\hline 2 & Kriteria & Baik & Baik Sekalii \\
\hline
\end{tabular}

Tabel 1 tersebut menunjukan hasil adanya peningkatan percaya diri siswa dari siklus I ke Siklus II. Peningkatan sikap percaya diri dapat dilihat pada gambar 2 histogram di bawah ini:

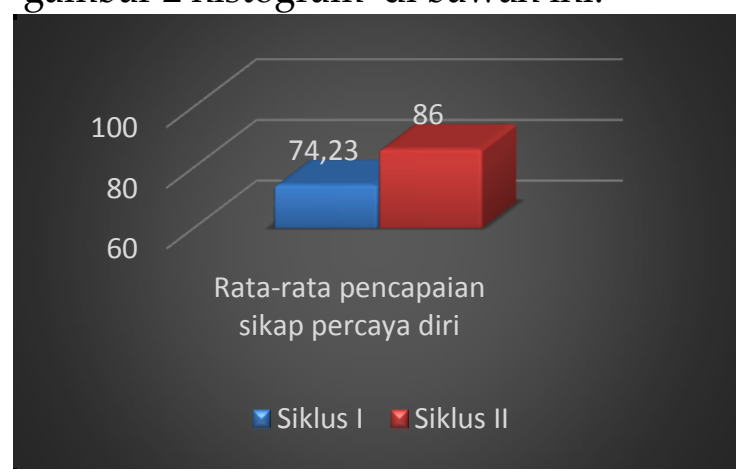

Gambar 2 Histogram Peningkatan Sikap Percaya Diri Siswa

Gambar 2 dapat diketahui bahwa sikap percaya diri siswa selama pembelajaran menggunakan strategi pembelajaran ATONG dengan bantuan media video berbasis powtoon mengalami peningkatan dari siklus I ke siklus II, adapun sikap percaya diri siswa pada siklus I diperoleh data rata-rata 74,23 dengan kriteria baik. Siklus II diperoleh rata-rata 86 dengan kriteria baik sekali, sehingga terjadi peningkatan sikap percaya diri siswa dari siklus I ke siklus II sebesar 11,77\%. Peningkatan sikap percaya diri siswa dari siklus I yang berkriteria baik meningkat pada siklus II menjadi kriteria baik sekali hal ini dikarenakan siswa yakin dalam kemampuan diri sendiri dalam mengikuti 


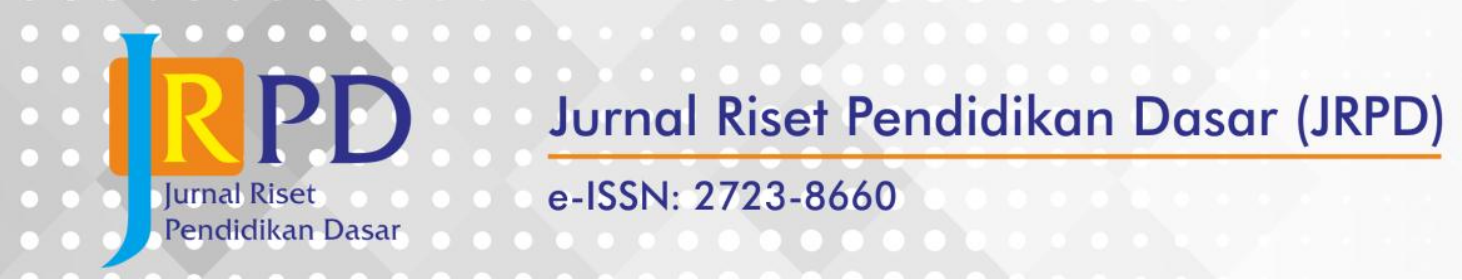

proses pembelajaran. Mustari (2014:51) mengungkapkan bahwa sikap percaya diri adalah sikap yakin akan kemampuan diri sendiri terhadap pemenuhan tercapainya setiap keinginan dan harapan. Pernyataan Mustari tersebut mengingatkan guru agar selalu mendorong dan memotivasi siswa untuk percaya akan kemampuan yang dimilikinya. Meningkatnya sikap percaya diri siswa mempengaruhi keaktifan siswa dalam mengikuti pembelajaran. Hal ini dibuktikan dengan hasil observasi sikap percaya diri siswa pada saat mengikuti pembelajaran menggunakan strategi pembelajan ATONG menggunakan media video berbasis powton dapat dilihat pada tabel 2 berikut ini:

Tabel 4.12 Hasil Rekapitulasi Observasi Sikap Percaya Diri Siswa

\begin{tabular}{cccc}
\hline No & $\begin{array}{c}\text { Pencapain } \\
\text { percaya diri } \\
\text { siswa }\end{array}$ & Siklus I & Siklus II \\
\hline 1 & Rata-Rata & 3,67 & 3,99 \\
\hline 2 & Kriteria & Baik & Baik \\
\hline
\end{tabular}

Pada tabel 2 dijelaskan bawah hasil observasi sikap percaya diri siswa mengikuti pembelajaran menggukan strategi pembelajaran ATONG berbantu media Video powton terjadi peningkatan dari siklus I ke siklus II, hal ini dapat dilihat secara jelas pada gambar 3 histogram dibawah ini:

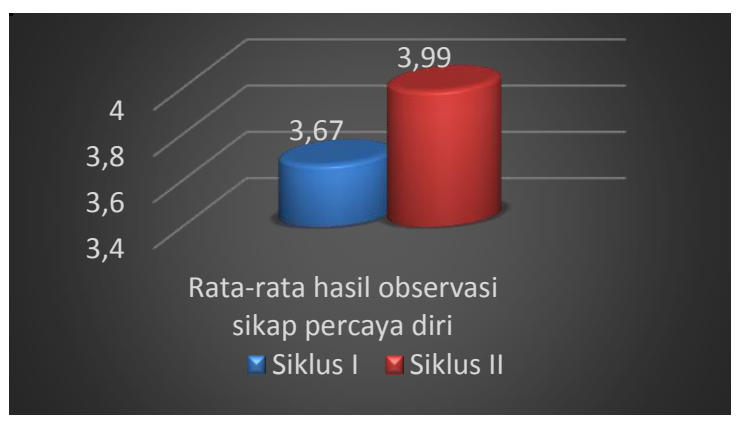


percaya diri dan yakin atas kemampuanya dengan dilihat pada saat mengerjakan soal evaluasi. Serta memiliki sifat yang pantang menyerah pada saat mengerjakan soal evaluasi. Perubahan tersebut tentu akan memberikan hasil prestasi yang baik.

Pada pembelajaran di siklus I dari awal siswa masih ragu untuk mengungkapkan pendapatnya dan masih diam saat diminta untuk menjawab pertanyaan yang diberikan oleh guru. Pada siklus II siswa terlihat mengalami perubahan sedikit demi sedikit dengan cara bertahap, dari mulai siswa yang pasif menjadi aktif walau ada salah satu siswa yang masih tetap pasif saat pembelajaranmterlihat dari beberapa aspek yang diamati pada sikap percaya diri.

Berdasarkan penilaian lembar angket sikap percaya diri, observasi sikap percaya diri dan dokumen yang telah dilakukan observer dan siswa, meningkatnya sikap percaya diri dapat terlihat dari saat proses pembelajaran dengan menggunakan strategi pembelajaran ATONG dengan bantuan media video berbasis powtoon. Pembelajaran dengan menggunakan strategi ATONG melalui beberapa tahap kegiatan yaitu tahap Amati, Tanya, Olah, Nalar, dan Gagas. Berdasarkan hasil pengamatan terdapat satu tahap strategi pembelajaran ATONG yang dapat meningkatkan sikap percaya diri siswa, yaitu terdapat di tahap Gagas. Pada tahap gagas, siswa diminta untuk mengkomunikasikan apa yang telah mereka pelajari selama kegiatan pembelajaran, melalui tahap ini siswa dilatih untuk berani dalam menyampaikan informasi yang sudah ia pelajari, belajar melawan rasa takut dan ragu, berlatih berbicara didepan kelas setelah dibekali informasi-informasi yang telah mereka dapatkan selama mengikuti pembelajaran. Hal ini sejalan dengan pendapatnya Muslim A.H dan Supriatna (2016:7) mengatakan bahwa dengan adanya informasi yang diperoleh membuat siswa tidak ragu dalam menyampaikan gagasannya sehingga rasa percaya diri siswa mengalami peningkatan.

Temuan yang lain adalah pada tahap Amati, siswa mulai menyadari pentingnya kemandirian dalam memberikan perhatian penuh terhadap kegiatan pembelajaran. Hal ini senada dengan pendapat Masriah (2015: 163) pada jurnal yang berjudul "pengembangan karakter mandiri dan pemecahan masalah melalui model pembelajaran MMP pendekatan ATONG materi geometri', bahwa terdapat pengaruh signifikan karakter mandiri dan keterampilan pemecahan masalah terhadap kemampuan pemecahan masalah sebesar $64 \%$ dan dapat meningkatkan karakter mandiri dan keterampilan pemecahan masalah pada subjek penelitian. Sikap mandiri dan tidak memerlukan bantuan orang lain inilah memunculkan pikiran positif terhadap diri sendiri sehingga siswa mampu menggali kemampuan dirinya sendiri secara optimal yang berdampak positif terhadap sikap percaya diri siswa.

Temuan yang lain adalah pada tahap Tanya, melalui tahap ini siswa dapat menanyakan materi yang kurang mereka pahami atau menanyakan sebuah pertanyaan yang mengali rasa ingin tahu siswa sehingga siswa ikut berperan aktif 
dalam kegiatan pembelajaran. Hal ini senada dengan pendapat Istiani (2015: 8) pada penelitian yang berjudul "Pembentukan berpikir kreatif dan rasa ingin tahu melalui model advance organizer berbasis atong materi geometri kelas VIII" bahwa melalui strategi ATONG terdapat pengaruh positif karakter rasa ingin tahu dan keterampilan berpikir kreatif terhadap kemampuan berpikir kreatif sebesar 46,3\%. melalui tahap ini mendorong dan menginspirasi siswa untuk aktif belajar, serta mampu mengembangkan pertanyaan yang berdampak positif terhadap sikap percaya diri siswa.

Peningkatan sikap percaya diri siswa tidak terlepas dari peran guru dalam melaksanakan pembelajaran yang aktif dan menyenangkan bagi siswa. Pembelajaran dengan menggunakan strategi ATONG dengan bantuan media video berbasis powtoon menjadikan kegiatan pembelajaran banyak melibatkan siswa secara langsung dalam kegiatan pembelajaran. Pembelajaran yang aktif dan menyenangkan tidak hanya pembelajaran untuk mentransfer ilmu pengetahuan dari guru ke siswa saja, akan tetapi melibatkan siswa didalam proses pembelajarannya. Melalui strategi ATONG dengan bantuan media video berbasis powtoon guru bisa memberikan ruang kepada siswa agar siswa aktif dalam kegiatan pembelajaran, yaitu dengan memberikan kesempatan kepada siswa agar siswa dapat bertanya ataupun mengungkapkan gagasannya.

Sikap percaya diri pada siswa setelah melaksanakan pembelajaran menggunakan strategi ATONG dengan bantuan media video berbasis powtoon muncul seperti mengekspresikan pendapat saat berdiskusi, saat maju untuk mempresentasikan hasil permasalahan yang ada pada pembelajaran siswa hanya sedikit mengalami keraguan. Aktivitas siswa juga meningkat secara bertahap, siswa memiliki rasa pantang menyerah dan yakin atas jawaban evaluasi yang sudah dikerjakannya.

Kepercayaan diri siswa muncul ketika guru mengetahui kemampuan siswa. Elfindri, dkk (2012: 137) menjelaskan kepercayaan diri harus diasah oleh guru di sekolah melalui serangkaian strategi proses belajar mengajar. Dengan menggunakan strategi ATONG guru dapat meningkatkan sikap percaya diri siswa karena dengan berdiskusi siswa saling memberikan pendapatnya, serta saling bekerja secara kooperatif dalam kelompoknya. Perubahan tingkah laku siswa dengan diasah guru menggunakan strategi ATONG, akan memberikan hasil prestasi yang baik, tidak hanya di dalam kelas tetapi di luar kelas atau di lingkungan.

Penggunaan media pembelajaran juga memudahkan guru dalam proses pembelajaran. Sanjaya (2010: 163) menjelaskan bahwa media bukan hanya berupa alat atau bahan saja, akan tetapi hal-hal lain yang memungkinkan siswa dapat memperoleh pengetahuan. Dengan menggunakan media video berbasis powtoon dalam penerapan pembelajaran menggunakan strategi ATONG sangatlah memiliki peran yang besar menjadikan siswa menjadi lebih percaya diri dalam memberikan pendapatnya dan pada saat berinteraksi dengan siswa lain.

Berdasarkan hasil penelitian tindakan kelas yang dilakukan di kelas V SD N Karangduren dapat disimpulkan bahwa melalui strategi ATONG dengan bantuan 
media video berbasis powtoon dapat meningkatkan sikap percaya diri siswa pada tema 6 panas dan perpindahannya. Hal ini di tunjukkan dengan hasil sikap percaya diri siswa yang telah mencapai indikator keberhasilan yang sudah ditentukan yaitu perolehan siswa pada hasil angket, observasi dan dokumen setiap siklus sekurang-kurangnya masuk kriteria baik.

\section{SIMPULAN}

Strategi pembelajaran ATONG dengan bantuan media video berbasis Powtoon dapat meningkatkan sikap percaya diri siswa pada siklus 1 yang ditunjukkan dengan hasil angket mencapai rata-rata jumlah skor 74,23 dengan kriteria baik dan hasil dari lembar observasi sikap percaya diri mencapai rata-rata jumlah skor 3,67 dengan kriteria baik, pada siklus II mengalami peningkatan yang ditunjukkan dengan hasil angket mencapai rata-rata jumlah skor 86 dengan kriteria baik sekali dan hasil dari lembar observasi sikap percaya diri mencapai rata-rata jumlah skor 3,99 dengan kriteria baik. Keterlibatan siswa yang membuat siswa aktif juga meningkat pada saat proses pembelajaran selama dua siklus.

\section{DAFTAR PUSTAKA}

Arikunto, S. Suhardjono. \& Supardi. (2010). Penelitian Tindakan Kelas. Jakarta.: PT. Bumi Aksara.

Aunnurahman. (2011). Belajar dan Pembelajaran. Bandung.: Alfabeta

Elfindri, Dkk (2012). Pendidikan Karakter Kerangka, Metode dan Apliasi Untuk Pendidik dan Profesional. Jakarta: Baduose Media Jakarta
Istiani, E. (2015). Pembentukan Berpikir Kreatif dan Rasa Ingin Tahu Melalui Model Advance Organizer Berbasis ATONG Materi Geometri Kelas VIII [Skripsi]. Semarang. Universitas Negeri Semarang.

Masriah. Susilo, B,E. Sukestiyarno. (2015). Pengembangan Karakter Mandiri dan Pemecahan Masalah Melalui Model Pembelajaran MMP pendekaran ATONG Materi Geometri. Journal of Mathematics Education. 4(2): 158-163.

Mulyasa. (2014). Pengembangan dan Implementasi Kurikulum 2013. Bandung.: Remaja Rosdakarya

Muslim, A.H. \& Supriatna. (2016). Pengembangan perangkat pembelajaran Pkn Model Cooperative tipe TGT Berbasis ATONG Bagi Siswa Sekolah Dasar. UM Purwokerto: Jurnal Pendidikan Sekolah Dasar 2(2): 114

Mustari, M. (2014). Nilai Karakter: Refleksi untuk Pendidikan. Jakarta.: Rajawali Press.

Sanjaya, W. (2010). Strategi Pembelajaran Berorientasi Standar Proses Pendidikan. Jakarta: Prenada Media Group.

Suhardita, K. (2011). Efektivitas Penggunaan Teknik Permainan dalam Bimbingan Kelompok untuk Meningkatkan Percaya Diri Siswa. (1): 127-138.

Yusnimar. (2016). Kompetensi pustakawan Universitas Islam Negeri Syarif Hidayatullah Jakarta menghadapi Masyarakat Ekonomi ASEAN (MEA). UIN Syarif Hidayatullah Jakarta: AlMaktabah.15: 95-110. 